\title{
Partial Incision of the Zona Pellucida using Piezo-micromanipulator Improves In Vitro Fertilization using Low-motility Spermatozoa of Infertile Transgenic Mice
}

\author{
Yosuke Kawase ${ }^{1,2 *}$, Nobuo Kamada ${ }^{1}$ and Hiroshi Suzuki ${ }^{1,3}$ \\ ${ }^{1}$ Chugai Pharmaceutical Co., Ltd. and \\ ${ }^{2}$ Chugai Research Institute for Medical Science, Inc., 1-135, Komakado, Gotemba, 412-8513 Japan, \\ ${ }^{3}$ National Research Center for Protozoan Diseases, Obihiro University of Agriculture and \\ Veterinary Medicine, Nishi 2-13, Inada, Obihiro, 080-8555 Japan
}

\begin{abstract}
To overcome infertility of male transgenic mice with low-motility spermatozoa, we examined the benefits of the zona pellucida incision using a piezomicromanipulator (ZIP) on in vitro fertilization (IVF) using low-motility spermatozoa. The incision was about $26 \mu \mathrm{m}$ long, representing $8 \%$ of the perimeter of the zona pellucida of the mature oocyte. Over $95 \%$ of cumulusfree oocytes survived after ZIP. The in vitro fertilization rate of ZIP oocytes by low-motility spermatozoa of the transgenic mice was $22-57 \%$, compared with $1-2 \%$ of cumulus-intact oocytes. After embryo transfer of ZIP zygotes at 2-cell stage into the oviducts of recipients, $11-20 \%$ of the transferred embryos developed to term. Our results indicate that ZIP is a useful technique for IVF of ova by low-motile spermatozoa and subsequent embryo transfer.
\end{abstract}

Key words: ART, Embryo transfer, Infertility, IVF, Mice

In vitro fertilization (IVF) is widely used clinically [1, 2] and experimentally $[3,4]$ for treatment of infertility. In transgenic mice, both male and female animals occasionally suffer from infertility in natural mating, presumably due to insertion of a foreign gene into the genome or disruption of the targeted gene of interest [5]. Thus, IVF has been applied to the establishment or maintenance of transgenic mice lines that exhibit subfertility and infertility such as oligospermia and low motility of spermatozoa. When fertilization cannot be achieved by conventional IVF methods due to low

Received: December 11, 2001

Accepted: February 8, 2002

*To whom correspondence should be addressed.

e-mail: kawaseysk-cms@chugai-pharm.co.jp quality or quantity of spermatozoa, partial zona pellucida dissection (PZD) or intracytoplasmic sperm injection (ICSI) techniques seem to be effective "assisted reproductive techniques" (ARTs) in mice. However, one drawback of PZD is the requirement for the PZD zygotes to be cultured in vitro up to the morula or blastocyst stage prior to embryo transfer because blastomeres often escape from the slit of the zona pellucida during the early stages of embryonic development and attach to epithelial cells of the oviduct [6]. On the other hand, the application of ICSI for massproduction in subfertile or infertile transgenic mice, especially those of C57BL/6J genetic background, seems to be difficult due to technical difficulties as well as a variety of factors affecting survival rate, fertilization rate and subsequent embryonic development after ICSI [7, 8]. In fact, results of ICSI in C57BL/6 show low survival rates and poor post-implantation development compared with those in hybrid $\mathrm{F} 1$ such as (C57BL/6 $\times$ $\mathrm{C} 3 \mathrm{H} / \mathrm{He}) \mathrm{F} 1$ and $(\mathrm{C} 57 \mathrm{BL} / 6 \times \mathrm{DBA} / 2) \mathrm{F} 1[8]$.

In the present study, we examined the effectiveness of another technique in improving fertilization and subsequent embryonic development using low-motility spermatozoa of an infertile transgenic mouse strain. In this technique, the zona pellucida is partially incised using a piezo-micromanipulator (ZIP), before fertilization using low-motility spermatozoa. ZIP was first developed as a method for improving both fertilization rates in vitro and subsequent embryonic development in cryopreserved genetically modified C57BL/6J spermatozoa [6]. Our results indicate that ZIP is a useful technique for IVF of ova by low-motile spermatozoa and subsequent embryo transfer. 

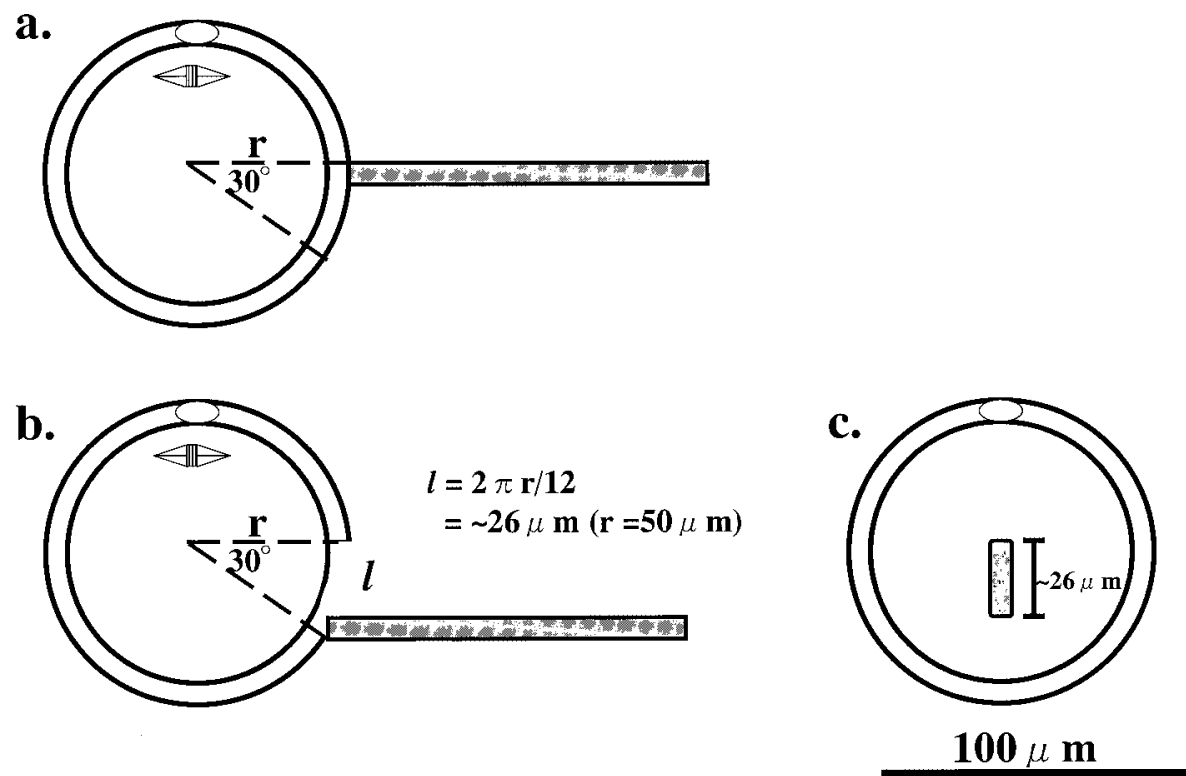

Fig. 1. The ZIP procedure for mouse oocyte. (a) The blunt end of the micropipette (tip diameter $=7 \mu \mathrm{m}$ ) touched the surface of the zona pellucida. (b) The zona pellucida was incised by applying piezo pulses to the micropipette tip while the pipette was advanced using a piezo-micromanipulator along the surface of the zona pellucida. The orbit of the movement of the tip of the pipette drew an arc in a plane, with an arc length of $\pi \mathrm{r} / 6 \mu \mathrm{m}$. (c) The length of the incision made in the zona pellucida using ZIP was approximately $26 \mu \mathrm{m}$.

\section{Materials and Methods}

C57BL/6J female mice (CLEA, Tokyo), 8-12 weeks old, were induced to superovulate by intraperitoneal injection of 5 i.u. equine chorionic gonadotrophin (eCG; Serotrophin, Teikokuzoki Co., Tokyo) followed $48 \mathrm{hr}$ later by ip injection of 5 i.u. human chorionic gonadotrophin (hCG; Puberogen, Sankyo Co., Tokyo). Freshly ovulated oocytes were collected from oviducts 15-16 hr after hCG injection. The oocytes were treated with $0.1 \%$ hyaluronidase ( 280 units/mg; $\mathrm{H}-3506$, Sigma Chemical Co., St. Louis, MO) in TYH medium [9] to remove cumulus cells. Spermatozoa were collected from the cauda epididymis of genetically modified mature $F 1$ male mice that had two lox $P$ sequences (5' ATAACTTCGTATAGCATACATTATACGAAGTTAT 3') and a neomycin resistant gene (unpublished). They were immediately suspended in $200 \mu \mathrm{l} \mathrm{TYH}$ medium covered with paraffin oil (no. 261-37: Nakalai Tesque, Kyoto, Japan) and incubated for $90 \mathrm{~min}$ at $37^{\circ} \mathrm{C}$ under $5 \% \mathrm{CO}_{2}$ in air. Since this strain of transgenic mouse is infertile in natural mating, motility and other parameters of sperm function were examined using a sperm analyzer, IVOS (Hamilton-Thorne Research, Beverly,
MA).

The holding pipette was prepared from a glass capillary tube (G1; Narishige, Tokyo, Japan). The capillary tube was heated and pulled using an automatic electromagnetic pipette puller (P-197; Sutter Instrument, Novato, CA). The tip of the pipette $(\sim 8 \mu \mathrm{m}$ in diameter) was polished using a microforge (De Fonbrune, Beaudouim, France). The micropipette for ICSI was used as a ZIP pipette, which was prepared from a glass capillary tube (O.D: $1.0 \mathrm{~mm}$, I.D: $0.75 \mathrm{~mm}$; Sutter Instrument) using a pipette puller (Sutter Instrument) and had a blunt-end. The outer diameter of the tip of the ZIP pipette was approximately $7 \mu \mathrm{m}$. A small volume $(\sim 0.5 \mu \mathrm{l})$ of mercury was introduced into the ZIP pipette from its proximal end. The pipette was connected to a Fluorinert (F77, Sumitomo 3M Co., Tokyo)-filled syringe system of the piezo-electric actuator (model PMM 150 FU; Prime Tech, Ibaraki, Japan) attached to a micromanipulator (Leica, Wetzlar, Germany). The zona pellucida was then incised by the micropipette through the application of piezo pulses (controller setting: speed 1 , intensity 2 ) while the pipette was moved along the surface of zona pellucida. The arc length of the ZIP was $\pi \mathrm{r} / 6 \mu \mathrm{m}$ (Fig. 1). 
Table 1. Motility and velocity of spermatozoa from infertile transgenic mice and C57BL/6J wild-type mice

\begin{tabular}{lccc}
\hline & $\begin{array}{c}\text { Transgenic } \\
\text { line A }\end{array}$ & $\begin{array}{c}\text { Transgenic } \\
\text { line B }\end{array}$ & C57BL/6J \\
\hline \% of motile & $57^{*}$ & $59^{*}$ & 75 \\
Path velocity $(\mu \mathrm{m} / \mathrm{s})$ & $76.0^{*}$ & $71.1^{*}$ & 101.8 \\
Progressive velocity $(\mu \mathrm{m} / \mathrm{s})$ & 49.7 & 48.2 & 64.5 \\
Track speed $(\mu \mathrm{m} / \mathrm{s})$ & $146.6^{*}$ & $138.5^{*}$ & 205.7 \\
Lateral head displacement $(\mu \mathrm{m})$ & $8.1^{*}$ & $7.7^{*}$ & 12.0 \\
\hline
\end{tabular}

$* \mathrm{P}<0.01$, compared to the corresponding $\mathrm{C} 57 \mathrm{BL} / 6 \mathrm{~J}$ wild-type mice.

Table 2. Effect of ZIP on the fertility of low-motility spermatozoa of transgenic mice

\begin{tabular}{ccccc}
\hline $\begin{array}{c}\text { Transgenic } \\
\text { mouse line }\end{array}$ & $\begin{array}{c}\text { No. of } \\
\text { experiment }\end{array}$ & Treatment & $\begin{array}{c}\text { No. of } \\
\text { inseminated ova }\end{array}$ & $\begin{array}{c}\text { No. (\%) of fertilized } \\
\text { oocytes }\end{array}$ \\
\hline A & 1 & ZIP & 79 & $45(57)^{*}$ \\
& 1 & None & 123 & $2(2)$ \\
B & 1 & ZIP & 102 & $22(22)^{*}$ \\
& 1 & None & 144 & $1(1)$ \\
\hline
\end{tabular}

*P $<0.01$, compared to the corresponding none treatment group.

Spermatozoa suspension was added to the medium containing the ZIP oocytes at a final concentration of 1.5 $\times 10^{5} \mathrm{cells} / \mathrm{ml}$. As a control, cumulus-intact oocytes were inseminated with the spermatozoa at a final concentration of $1.5 \times 10^{5}$ cells $/ \mathrm{ml}$. At $6 \mathrm{hr}$ after insemination, the oocytes were washed three times in Whitten's medium [10] containing $100 \mu \mathrm{M}$ EDTA [11] and cultured up to the 2-cell stage in $5 \% \mathrm{CO}_{2}$ in air at $37^{\circ} \mathrm{C}$. Fertilization was defined by the number of embryos that had developed to the 2-cell stage at $24 \mathrm{hr}$ after insemination. Two-cell stage embryos were subsequently transferred into the oviducts of the psuedopregnant recipients on 0.5 day post-coitum (dpc) [12]. The recipients were sacrificed on $19.5 \mathrm{dpc}$.

All mice were housed in polycarbonate cages and maintained in a specific pathogen-free environment in light-controlled (lights-on from 05:00 to 19:00), and airconditioned rooms (temperature: $24 \pm 1^{\circ} \mathrm{C}$, humidity: 50 $\pm 10 \%$ ). They had free access to standard laboratory chow (CA-1; CLEA Japan, Tokyo) and water. The animals used in this study were cared for and used under the Guiding Principles for the Care and Use of Research Animals promulgated by Chugai Pharmaceutical, Shizuoka, Japan.

Data presented in this study were analyzed statistically by Student's t-test (Table 1) and chi-square test (Table 2). Differences between groups were considered significant when $p$ was $<0.01$.

\section{Results}

The mean percentage of motile spermatozoa from transgenic mice was less than $60 \%$, and lateral head displacement of the spermatozoa was 7.7-8.1 $\mu \mathrm{m}$ for both lines $A$ and $B$ of transgenic mice. The mean value of lateral head displacement of spermatozoa of transgenic mice was approximately $75 \%$ of that of C57BL/6J wild-type mice (Table 1). The mean percentage of motile spermatozoa, path velocity, track speed and lateral head displacement of spermatozoa from both transgenic mice were significantly lower than those from C57BL/6J wild-type mice $(P<0.01$, respectively). The spermatozoa of C57BL/6J wild-type mice fertilized $79 \%(186 / 234)$ of oocytes using a conventional IVF method.

The partial incision of the zona pellucida did not compromise the survival of oocytes; the survival rate of C57BL/6J oocytes, subjected to zona pellucida incision by $\pi \mathrm{r} / 6 \mu \mathrm{m}$ long ZIP, was $96 \%(185 / 193)$. IVF of ZIP oocytes by low-motility spermatozoa from lines $A$ and $B$ transgenic mice was successful in $57 \%$ and $22 \%$ of oocytes, respectively. In contrast, only a few cumulusintact oocytes were fertilized by spermatozoa from lines $A$ and $B$ transgenic mice (Table 2). The difference in fertilization rates between ZIP oocytes and cumulusintact oocytes was statistically significant for each line $(P<0.01)$. These results indicate that the ZIP procedure significantly improved the in vitro fertilization ability of 
Table 3. Postimplantation development of embryos produced by ZIP

\begin{tabular}{cccc}
\hline Line & $\begin{array}{c}\text { No. of } \\
\text { transferred embryos }\end{array}$ & $\begin{array}{c}\text { No. (\%) of } \\
\text { implantation sites }\end{array}$ & $\begin{array}{c}\text { No. (\%) of } \\
\text { live fetuses }\end{array}$ \\
\hline A & 40 & $11(28)$ & $8(20)$ \\
B & 18 & $3(17)$ & $2(11)$ \\
\hline
\end{tabular}

Embryos at the 2-cell stage were transferred to the oviducts of recipients.

the low-motility spermatozoa of the transgenic mice.

When ZIP zygotes at the 2-cell stage were transferred into oviducts, $20 \%$ and $11 \%$ of the transferred embryos that had been fertilized with lines $A$ and $B$ spermatozoa developed to term, respectively (Table 3). Approximately half of the newborns were identified as transgenic mice by Southern blot analysis (data not shown).

\section{Discussion}

Undoubtedly, IVF is an effective ART for reproduction in humans, mice and other mammalian spices. However, the efficiency of IVF is influenced among other factors by the functional and kinetic properties of the spermatozoa [13] as well as the quality of oocytes [14]. The limitations of IVF could probably be overcome, at least in part, by combining the procedure with other ARTs such as PZD [15] and ZIP [6]. In fact, we have already reported that the use of cryopreserved mouse spermatozoa in IVF in combination with PZD resulted in a marked increase in fertilization rates [15]. In this regard, the new ART, ZIP, was developed to improve both fertilization rates in vitro and, more importantly, pre- and post-implantation development in vivo in mice [6]. This technique involves the creation of a partial incision of the oocyte using piezo pulses prior to fertilization. Application of the ZIP technique has been reported to markedly increase the IVF rates of cryopreserved genetically-modified spermatozoa of C57BL/6J mice and allow the successful transfer of zygotes into the oviducts of recipients [6]. The development rates of ZIP zygotes transferred at the 2cell stage have been similar to those of 2-cell zygotes without ZIP [6].

The piezo-electric actuator has also been used as an instrument for ARTs such as ICSI in the laboratory $[7,8$, 16-19], domestic animals [20-22] and humans [23-25], production of chimeric embryos [26, 27] and assisted hatching [28, 29], as well as transgenesis [18] and cloning [30-36]. The piezo-electric actuator has been used mainly for injection of certain materials into the oocytes or embryos. We used IVF in combination with ZIP to overcome the infertility of a transgenic mouse strain. The zona pellucida of oocytes was easily incised/cut by ZIP without any additional treatment such as the use of hypertonic solution or subsequent successive washing as normally used in the PZD method [6]. The length of the incision made in the zona pellucida using the ZIP technique was $26 \mu \mathrm{m}$, representing about $8 \%$ of the perimeter of the zona pellucida of the mature mouse oocyte $(\sim 314 \mu \mathrm{m}$, Fig. 1). The incision allows eggs to be fertilized, which can be transferred to the oviducts of recipient animals [6]. In our study, none of the unfertilized ZIP oocytes developed to the 2-cell stage (data not shown), confirming that parthenogenetic activation similar to that reported in the zona opening procedure, of oocytes was not induced by ZIP treatment [37]. When the zona pellucida of C57BL/6J wild-type mice zygotes was incised by ZIP and such zygotes were subsequently transferred at the 2-cell stage into the oviducts of recipient mice, rates of implantation and embryonic development to full-term fetuses were not different from those of untreated control zygotes [6]. Consequently, it appears that ZIP treatment does not affect pre- and post-implantation development of mouse zygotes.

The transgenic mouse strain used in the present study exhibited infertility in natural mating and subfertility in conventional IVF (Table 2). Our results show that ZIP significantly increased the fertilization rate using low-motility spermatozoa of transgenic mice (Table 2) and a proportion of fertilized ZIP zygotes developed to term after transfer of the embryo into the oviducts of recipient animals (Table 3 ). These results clearly demonstrate that IVF in combination with ZIP is an effective ART for reproduction of infertile transgenic mice with low-motility spermatozoa, in addition to that reported for cryopreserved mouse spermatozoa [6].

\section{Acknowledgments}

We thank T. Iwata for excellent technical assistance and $\mathrm{K}$. Jishage for invaluable discussion. 


\section{References}

1) Wood, C. and Trounson, A.O. (2000): Historical perspectives of IVF. In: Handbook of In vitro Fertilization. 2nd ed. (Trounson, A.O. and Gardner, D.K., eds.), pp. 114, CRC Press, Florida.

2) Brandell, R.A. and Schlegel, P.N. (2000): Evaluation of male infertility. In: Handbook of the Assisted Reproduction Laboratory. (Keel, B.A., May, J.V. and De Jonge, C.J., eds.), pp. 77-96, CRC Press, Florida.

3) Suzuki, H., Shingai S., Togashi, M., Miyai, T. and Okamoto, M. (1987): In vitro fertilization and the development of eggs following transfer in genetically diabetic obese (db/db) mouse. Jpn. J. Anim. Reprod., 33, 96-100.

4) Yokoyama, M., Katsuki, M. and Nomura, T. (1995): The creation of mouse models for human disease associated with reproductive disturbances by in vitro fertilization and embryo transfer. Exp. Anim., 44, 139-143.

5) Escalier, D. (2001): Impact of genetic engineering on the understanding of spermatogenesis. Hum. Reprod. Update, 7, 191-210.

6) Kawase, Y., Iwata, T., Ueda, O., Kamada, N., Tachibe, T., Aoki, Y., Jishage, K. and Suzuki, H. (2002): Effect of partial incision of the zona pellucida by piezo micromanipulator for in vitro fertilization using frozenthawed mouse spermatozoa on the developmental rate of embryos transferred at the 2-cell stage. Biol. Reprod., 66, 381-385.

7) Kishikawa, H., Tateno, H. and Yanagimachi, R. (1999): Chromosome analysis of BALB/c mouse spermatozoa with normal and abnormal head morphology. Biol. Reprod., 61, 809-812.

8) Kawase, Y., Iwata, T., Toyoda, Y., Wakayama, T., Yanagimachi, R. and Suzuki, H. (2001): Comparison of intracytoplasmic sperm injection of inbred and hybrid mice. Mol. Reprod. Dev., 60, 74-78.

9) Toyoda, Y., Yokoyama, M. and Hosi, T. (1971): Studies on the fertilization of mouse eggs in vitro. I. In vitro fertilization of mouse eggs by fresh epididymal sperm. Jpn. J. Anim. Reprod., 16, 147-151.

10) Whitten, W.K. (1971): Nutrient requirements for the culture of preimplantation embryos in vitro. Adv. Biosci., 6, 129-141.

11) Abramczuk, J., Solter, D. and Koprowski, H. (1977): The beneficial effect of EDTA on development of mouse onecell embryos in chemically defined medium. Dev. Biol., 61, 378-383.

12) Suzuki, H., Ueda, O., Kamada, N., Jishage, K., Katoh, M. and Shino, M. (1994): Improved embryo transfer into the oviduct by local application of a vasoconstrictor in mice. J. Mamm. Ova. Res., 11, 49-53.

13) Malter, H.E. and Cohen, J. (1989): Partial zona dissection of the human oocyte: a nontraumatic method using micromanipulation to assist zona pellucida penetration. Fetil. Steril., 51, 139-148.

14) Suzuki, H., Togashi, M., Moriguchi, Y. and Adachi, J.
(1994): Relationship between age-related decline in fertility and in vitro fertilization rate in IVCS mice. J. Reprod. Dev., 40, 107-116.

15) Nakagata, N., Okamoto, M., Ueda, O. and Suzuki, H. (1997): Positive effect of partial zona pellucida dissection on the in vitro fertilizing capacity of cryopreserved C57BL/ $6 \mathrm{~J}$ transgenic mouse spermatozoa of low motility. Biol. Reprod., 57, 1050-1055.

16) Kimura, Y. and Yanagimachi, R. (1995): Intracytoplasmic sperm injection in the mouse. Biol. Reprod., 52, 709-720.

17) Wakayama, T. and Yanagimachi, R. (1998): Development of normal mice from oocytes injected with freeze-dried spermatozoa. Nature. Biotech., 16, 639-641.

18) Perry, A.C.F., Wakayama, T., Kishikawa, H., Kasai, T., Okabe, M., Toyoda, Y. and Yanagimachi, R. (1999): Mammalian transgenesis by intracytoplasmic sperm injection. Science, 284, 1180-1183.

19) Dozortsev, D., Wakayama, T., Ermilov, A. and Yanagimachi, R. (1998): Intracytoplasmic sperm injection in the rat. Zygote, 6, 143-147.

20) Katayose, H., Yanagida, K., Shinoki, T., Kawahara, T., Horiuchi, T. and Sato, A. (1999): Efficient injection of bull spermatozoa into oocytes using a Piezo-driven pipette. Theriogenology, 52, 1215-1224.

21) Sutter, R., Zakhartchenko, V., Stojkovic, P., Muller, S., Alberio, R., Medjugorac, I., Brem, G., Wolf, E. and Stojkovic, M. (2000): Intracytoplasmic sperm injection in bovine: effects of oocyte activation, sperm pretreatment and injection technique. Theriogenology, 54, 935-948.

22) Wei, H. and Fukui, Y. (2000): Fertilisability of ovine, bovine or mink whale (Balaenoptera acutorostrata) spermatozoa intracytoplasmically injected into bovine oocytes. Zygote, 8, 267-274.

23) Huang, T., Kimura, Y. and Yanagimachi, R. (1996): The use of piezo micromanipulator for intracytoplasmic sperm injection of human oocytes. J. Assist. Reprod. Genet., 13, 320-328.

24) Yanagida, K., Katayose, H., Yazawa, H., Kimura, Y., Konnai, K. and Sato, A. (1999): The usefulness of a piezomicromanipulator in intracytoplasmic sperm injection in humans. Human Reprod., 14, 448-453.

25) Yanagida, K., Ktayose, H., Hirata, S., Yazawa, H., Hayashi, S. and Sato, A. (2001): Influence of sperm immobilization on onset of $\mathrm{Ca}^{2+}$ oscillations after ICSI. Human Reprod., 16, 148-152.

26) Onishi, A., Takeda, K., Komatsu, M., Akita, T. and Kojima, T. (1994): Production of chimeric pigs and the analysis of chimerism using mitochondrial deoxyribonucleic acid as a cell marker. Biol. Reprod., 51, 1069-1075.

27) Kawase, Y., Iwata, T., Watanabe, M., Kamada, N., Ueda, O. and Suzuki, H. (2001): Application of the piezomicromanipulator for injection of embryonic stem cells into mouse blastocysts. Lab. Anim. Sci., 40, 31-34.

28) Nakayama, T., Fujiwara, H., Tatsumi, K., Fujita, K., Higuchi, T. and Mori, T. (1998): A new assisted hatching technique using a piezo-micromanipulator. Fertil. Steril., 
69, 784-788.

29) Nakayama, T., Fujiwara, H., Yamada, S., Tatsumi, K., Honda, T. and Fujii, S. (1999): Clinical application of a new assisted hatching method using a piezomicromanipulator for morphologically low-quality embryos in poor-prognosis infertile patients. Fertil. Steril., 71, 1014-1018.

30) Wakayama, T., Perry, A.C.F., Zuccotti, M., Johnson, K. and Yanagimachi, R. (1998): Full term development of mice from enucleated oocytes injected with cumulus cells nuclei. Nature, 394, 369-373.

31) Wakayama, T., Rodriguez, I., Perry, A.C.F., Yanagimachi, R. and Mombaerts, P. (1999): Mice cloned from embryonic stem cells. Proc. Natl. Acad. Sci. USA, 96, 14984-14989.

32) Wakayama, T. and Yanagimachi, R. (1999): Cloning of mice from adult tail-tip cells. Nature Genet., 22, 127-128.

33) Wakayama, T., Tateno, H., Mombaerts, P. and Yanagimachi, R. (2000): Nuclear transfer into mouse zygotes. Nature Genet., 24, 108-109.

34) Rideout, W.M. III, Wakayama, T., Wutz, A., Eggan, K., Jackson-Grusby, L., Dausman, J., Yanagimachi, R. and Jaenisch, R. (2000): Generation of mice from wild-type and targeted ES cell by nuclear cloning. Nature Genet., 24, 109-110.

35) Ogura, A., Inoue, K., Ogonuki, N., Noguchi, A., Takano, K., Nagano, R., Suzuki, O., Lee, J., Ishino, F. and Matsuda, J. (2000): Production of male cloned mice from fresh, cultured and cryopreserved immature Sertoli cells. Biol. Reprod., 62, 1579-1584.

36) Onishi, A., Iwamoto, M., Akita, T., Mikawa, S., Takeda, K., Awata, T., Hanada, H. and Perry, A.C.F. (2000): Pig cloning by microinjection of fetal fibroblast nuclei. Science, 289, 1188-1190.

37) Odawara, Y. and Lopata, A. (1989): A zona opening procedure for improving in vitro fertilization at low sperm concentrations: a mouse model. Fertil. Steril., 51, 699-704. 